\title{
Heterogeneous detection of circulating tumor cells in patients with colorectal cancer by immunomagnetic enrichment using different EpCAM-specific antibodies
}

\author{
Dalibor Antolovic, Luis Galindo†', Anina Carstens, Nuh Rahbari, Markus W Büchler, Jürgen Weitz and Moritz Koch*
}

\begin{abstract}
Background: Circulating tumor cells (CTC) and disseminated tumor cells (DTC) are thought to be responsible for metastasis, so the detection of CTC may serve as individual prognostic factor in patients suffering from colorectal cancer. Therefore, a series of immunomagnetic enrichment methods for CTC have been developed using a variety of monoclonal antibodies against the Epithelial Cell Adhesion Molecule (EPCAM). However, it remains unclear whether all commercially available EpCAM antibodies show the same sensitivity and specificity. Furthermore, it remains unclear which method of sample preparation and cell extraction is most suitable for immunomagnetic enrichment and detection of CTC. In this study, we aimed to investigate whether the detection of CTC by a cytokeratin 20 reverse transcriptase-polymerase chain reaction (CK20 RT-PCR) may be influenced by the use of various Epithelial Cell Adhesion Molecule (EpCAM) antibodies for immunomagnetic isolation of CTC.

Results: Using both EpCAM antibodies (mAb BerEP4 and mAb KS1/4) for immunomagnetic enrichment in blood samples of 39 patients with colorectal cancer we found heterogenous results in each patient with regard to tumor cell detection. In the tumor cell spiking experiments with whole blood samples the sensitivity of the CK 20 RT-PCR assay was higher using immunomagnetic beads coated with mAb KS1/4 compared to precoated mAb BerEP4 Dynabeads. Extraction of MNC fraction with Ficoll gradient centrifugation prior to immunomagnetic enrichment resulted in a higher sensitivity of the CK 20 RT-PCR assay.

Conclusions: We concluded that isolation and detection of CTC with immunomagnetic enrichment methods is critically dependent on the used EpCAM clone. Further studies with a larger number of patients should clarify if the enrichment protocol influences the prognostic value of the tumor cell detection protocol.
\end{abstract}

\section{Background}

Detection of circulating tumor cells (CTC) in blood and disseminated tumor cells (DTC) in the bone marrow and/ or lymph nodes, which are thought to be responsible for metastases, may allow a better prediction of the individual prognosis of patients with colorectal cancer [1-3]. Recent studies of our group indicated that the molecular detection of CTC and DTC in patients with colorectal cancer (CRC) may be of prognostic value [4-7]. Furthermore, immunomagnetic enrichment strategies have been

\footnotetext{
* Correspondence: moritz.koch@med.uni-heidelberg.de

1 Department of Surgery, University of Heidelberg, Heidelberg, Germany + Contributed equally

Full list of author information is available at the end of the article
}

developed to improve the detection and yield of CTC and DTC [8]. A large number of monoclonal antibodies $(\mathrm{mAb})$ against the Epithelial Cell Adhesion Molecule (EpCAM) which is expressed only in epithelium and malignant tumors derived from epithelia have been increasingly used to enrich and isolate CTC from blood and DTC from bone marrow samples $[9,10]$. However, there are no data available comparing antibodies against various EpCAM epitopes for immunomagnetic isolation of CTC with regard to their sensitivity and specificity. Therefore, it remains unclear if all anti-EpCAM antibodies are able to detect and to capture the same range of CTC and if they have the same clinical and prognostic 
impact. Furthermore, it is still unknown which method of sample preparation and cell extraction is most suitable for immunomagnetic enrichment and detection of CTC.

In this study, we aimed to compare two different specific antibodies against the epitope in the EGF-like domain I of EpCAM for immunomagnetic enrichment and subsequent detection of CTC in CRC patients. We used commercially available immunomagnetic beads coated with mAb BerEP4 [11] and magnetic beads coated with mAb KS1/4 [12]. Both monoclonal antibodies recognize specific epitopes of the extracellular domain of the EpCAM molecule. mAb BerEP4 recognizes two $(34 \mathrm{kDa}$ and $39 \mathrm{kDa}$ ) specific antigens, whereas $\mathrm{mAb} \mathrm{KS} 1 / 4$ recognizes one $(40-42 \mathrm{kDa})$ specific antigen of the extracellular domain of the EpCAM molecule [10]. Furthermore, we examined the effect of two different cell extraction protocols on subsequent immunomagnetic enrichment and detection of tumor cells in the blood.

\section{Results}

Specificity of the enrichment and extraction protocols

Both whole blood and MNC fractions of five healthy donors were tested regarding the specificity of cell extraction and enrichment protocols with immunomagnetic beads coated with BerEP4 and KS1/4. No CK20 signal was observed in all examined blood samples of healthy donors, demonstrating the specificity of the used assays.

\section{Sensitivity of the enrichment and extraction protocols Whole Blood}

In the tumor cell spiking experiments with whole blood samples the sensitivity of the CK20 RT-PCR assay was higher using immunomagnetic beads coated with mAb KS1/4 compared to precoated mAb BerEP4 Dynabeads. In serial dilution assays, a minimum number of $10^{4} \mathrm{HT} 29$ cells could be detected in $5 \mathrm{ml}$ whole blood using the BerEP4 mAb whereas $10^{3}$ HT29 cells could be detected in the same volume using the KS1/4 mAb.

\section{Mononuclear cell fraction}

Extraction of MNC fraction with Ficoll gradient centrifugation prior to immunomagnetic enrichment of blood samples spiked with HT29 cells resulted in a higher sensitivity of the CK20 RT-PCR assay. $10^{3}$ HT29 cells spiked in $5 \mathrm{ml}$ blood (200 cells $/ \mathrm{ml}$ ) could be detected after isolation of the MNC fraction using the mAb BerEP4 Dynabeads, whereas $10^{2} \mathrm{HT} 29$ cells spiked in $5 \mathrm{ml}$ blood $(20$ cells $/ \mathrm{ml}$ ) were detected using the mAb KS1/4 coated beads.

Blood spiking experiments were repeated several times to confirm the above mentioned results.

The observed higher sensitivity of tumor cell detection after isolation of the MNC fraction prior to immunomagnetic CTC enrichment prompted us to generally use Ficoll gradient centrifugation before further immuno- magnetic enrichment and detection of CTC in the blood of CRC patients.

\section{Detection of tumor cells in blood samples of CRC patients}

Median age of included CRC patients was 63 years (range 27 - 90) with 16 females and 23 males. Eighteen of 39 (46\%) patients presented with metastatic disease to the liver and were classified as UICC stage IV; 7 patients were UICC stage III, and 7 patients stage UICC II and I. Clinical data of the patients are shown in Table 1.

Using two different antibodies (mAb BerEP4 and mAb KS1/4) for immunomagnetic enrichment, CTC were detected in 11 of 39 (28\%) patients with CRC. Among these, immunomagnetic enrichment with mAb BerEP4 beads accounted for $6 \mathrm{CK} 20$ positive patients. Immunomagnetic enrichment using mAb KS1/4 beads showed 5 CK20 positive patients. Interestingly, there were no blood samples being CK 20 positive for both used antibodies (Table 2 and Figure 1).

CK20 PCR transcripts were detected in 3 of 18 (17\%) blood samples from UICC stage IV patients after immunomagnetic enrichment with mAb KS1/4 coated beads. When mAb BerEP4 beads were used, we also observed positive CK20 products in 3 of 18 (17\%) UICC stage IV patients. Among the 7 patients with UICC stage III, 3 patients showed CK20 positive samples after enrichment of CTC with BerEP4 beads only. Positive CK20 signals were observed in 2 of 7 patients with UICC stage I after enrichment with KS1/4 coated beads only (see Table 3). Furthermore, among 7 patients with UICC stage II no samples were found positive for CK20 using either BerEP4 or KS1/4 coated beads.

\section{Discussion}

The first phase of the metastatic process of malignant epithelial tumors consists of local tumor cell migration, followed by tumor cell dissemination in the blood, invasion and homing to secondary distant organs [13,14]. Despite recent developments of various therapeutic approaches, distant metastases represent the major cause of death in patients with colorectal cancer [14]. Theoretically, postoperative metastatic recurrence should develop from isolated tumor cells or micrometastases already existing at time of surgery or they can derive from tumor cells that are hematogenously shed into circulation during surgical procedures. Thus, a reliable detection method for CTC in a small volume of peripheral blood might be of high interest to improve staging and to more accurately predict patients' individual prognosis. To increase the specificity of tumor cell detection, immunomagnetic beads labeled with an epithelium-specific monoclonal antibody (mAb) haven been used to isolate CTC from blood [15]. 
Table 1: Clinical data of our patient cohort with colorectal cancer.

\begin{tabular}{|c|c|c|c|c|c|c|c|}
\hline Pat. No. & Age & Gender & Tumor Location & TNM & UICC & $\begin{array}{c}\text { Multimodal } \\
\text { Therapy } \\
\text { before } \\
\text { Surgery }\end{array}$ & Therapy \\
\hline 1 & 67 & $\mathrm{~F}$ & $\begin{array}{l}\text { Metachronous liver metastasis } \\
\text { from Colon Cancer }\end{array}$ & Tx Nx M1 & IV & adjuvant & Liver resection \\
\hline 2 & 81 & M & Rectum & T3 N2 M0 & III & no & Anterior Rectal Resection \\
\hline 3 & 63 & $\mathrm{~F}$ & Rectum & T1 No Mo & 1 & no & Anterior Rectal Resection \\
\hline 4 & 65 & M & Rectum & T3 NO MO & $\|$ & neoadjuvant & Anterior Rectal Resection \\
\hline 5 & 71 & M & Colon, right & T2 NO MO & 1 & no & Colectomy, right \\
\hline 6 & 60 & M & $\begin{array}{l}\text { Synchronous liver metastasis } \\
\text { from Rectal Cancer }\end{array}$ & T2 No M1 & IV & no & Anterior Rectal Resection \\
\hline 7 & 45 & $\mathrm{~F}$ & Colon, left & T4 N1 M0 & III & no & Colectomy, left \\
\hline 8 & 68 & $\mathrm{~F}$ & Colon, right & T1 No Mo & 1 & no & Colectomy, right \\
\hline 9 & 68 & M & $\begin{array}{l}\text { Metachronous liver metastasis } \\
\text { from Rectal Cancer }\end{array}$ & Tx Nx M1 & IV & neoadjuvant & Liver resection \\
\hline 10 & 78 & $\mathrm{~F}$ & Local Relapse of Rectal Cancer & T4 NO MO & II & adjuvant & $\begin{array}{l}\text { Abdominoperineal Rectal } \\
\text { Resection and IORT* }\end{array}$ \\
\hline 11 & 62 & M & Rectum & T3 NO MO & II & no & Anterior Rectal Resection \\
\hline 12 & 53 & M & $\begin{array}{l}\text { Metachronous liver metastasis } \\
\text { from Colon cancer }\end{array}$ & Tx NxM1 & IV & adjuvant & Hemihepatectomy, right \\
\hline 13 & 64 & M & $\begin{array}{l}\text { Synchronous liver and lung } \\
\text { metastasis from Colon Cancer }\end{array}$ & T4 N2 M1 & IV & no & palliative Colectomy, right \\
\hline 14 & 45 & M & Local Relapse of Rectal Cancer & T3 NO MO & $\|$ & adjuvant & $\begin{array}{c}\text { Anterior Rectal Resection } \\
\text { and IORT* }\end{array}$ \\
\hline 15 & 74 & $\mathrm{~F}$ & Colon, left & T1 No M0 & 1 & no & Colectomy, left \\
\hline 16 & 52 & M & Colon, left & T1 No Mo & 1 & no & Colectomy, left \\
\hline 17 & 78 & M & Colon, right & T3 N1 Mo & III & no & Colectomy, right \\
\hline 18 & 72 & $\mathrm{~F}$ & Colon, right & T1 No Mo & 1 & no & Colectomy, right \\
\hline 19 & 54 & $\mathrm{~F}$ & Colon, left & T4 NO MO & $\|$ & no & $\begin{array}{c}\text { Anterior Rectal Resection } \\
\text { and IORT* }\end{array}$ \\
\hline 20 & 54 & $\mathrm{~F}$ & $\begin{array}{l}\text { Metachronous liver metastasis } \\
\text { from Colon Cancer }\end{array}$ & Tx Nx M1 & IV & adjuvant & Hemihepatectomy, right \\
\hline 21 & 64 & $\mathrm{~F}$ & $\begin{array}{l}\text { Metachronous liver metastasis } \\
\text { from Rectal Cancer }\end{array}$ & Tx Nx M1 & IV & no & palliative loop-lleostomy \\
\hline 22 & 44 & M & $\begin{array}{l}\text { Synchronous liver metastasis } \\
\text { from Colon Cancer }\end{array}$ & T3 N2 M1 & IV & no & Anterior Rectal Resection \\
\hline 23 & 73 & M & $\begin{array}{l}\text { Metachronous liver metastasis } \\
\text { from Rectal Cancer }\end{array}$ & Tx Nx M1 & IV & no & palliative loop-lleostoma \\
\hline 24 & 63 & M & $\begin{array}{l}\text { Metachronous liver metastasis } \\
\text { from Colon Cancer }\end{array}$ & T3 No M1 & IV & adjuvant & Rectosigmoid Resection \\
\hline 25 & 27 & M & Colon, right & T4 N2 M0 & III & no & Colectomy, right \\
\hline 26 & 68 & $\mathrm{~F}$ & Colon, right & T3 N1 M0 & III & no & Colectomy, right \\
\hline 27 & 47 & M & Rectum & T3 N1 M0 & III & neoadjuvant & $\begin{array}{c}\text { Anterior Rectal Resection } \\
\text { and IORT* }\end{array}$ \\
\hline 28 & 68 & M & $\begin{array}{l}\text { Synchronous liver and bone } \\
\text { metastasis from Colon Cancer }\end{array}$ & Tx Nx M1 & IV & no & $\begin{array}{l}\text { palliative Bypass } \\
\text { Ileotransversostomy }\end{array}$ \\
\hline 29 & 76 & M & $\begin{array}{l}\text { Metachronous liver metastasis } \\
\text { from Colon Cancer }\end{array}$ & Tx Nx M1 & IV & adjuvant & Liver resection \\
\hline 30 & 62 & M & $\begin{array}{l}\text { Metachronous liver metastasis } \\
\text { from Colon Cancer }\end{array}$ & Tx Nx M1 & IV & adjuvant & Exploration, Biopsy \\
\hline
\end{tabular}


Table 1: Clinical data of our patient cohort with colorectal cancer. (Continued)

\begin{tabular}{|c|c|c|c|c|c|c|c|}
\hline 31 & 62 & $M$ & Rectum & T1 N0 M0 & $\mathrm{I}$ & no & Anterior Rectal Resection \\
\hline 32 & 78 & $\mathrm{~F}$ & $\begin{array}{l}\text { Metachronous liver metastasis } \\
\text { from Rectal Cancer }\end{array}$ & Tx Nx M1 & IV & no & $\begin{array}{c}\text { Segment } 2 \text { and } 3 \text { Liver } \\
\text { resection }\end{array}$ \\
\hline 34 & 86 & $\mathrm{~F}$ & Rectum & T3 NO MO & II & no & Anterior Rectal Resection \\
\hline 35 & 44 & $\mathrm{~F}$ & $\begin{array}{l}\text { Local Relapse Colon Cancer, } \\
\text { Peritonealcarcinosis }\end{array}$ & T4 N2 M1 & IV & adjuvant & Laparotomy and Biopsy \\
\hline 36 & 90 & $\mathrm{~F}$ & Colon, left & T4 N1 M0 & III & no & Colectomy, left \\
\hline 37 & 55 & M & $\begin{array}{c}\text { Metachronous liver metastasis } \\
\text { from Rectal Cancer }\end{array}$ & $\mathrm{T} \times \mathrm{N} \times \mathrm{M} 1$ & IV & adjuvant & Hemihepatectomy, right \\
\hline 38 & 56 & M & $\begin{array}{l}\text { Synchronous liver metastasis } \\
\text { from Colon Cancer }\end{array}$ & T4 N1 M1 & IV & adjuvant & Hemihepatectomy, left \\
\hline 39 & 63 & $\mathrm{~F}$ & $\begin{array}{l}\text { Metachronous liver metastasis } \\
\text { from Rectal Cancer }\end{array}$ & Tx Nx M1 & IV & adjuvant & Hemihepatectomy, right \\
\hline
\end{tabular}

*Abbreviations: IORT: intraoperative radiotherapy; F: female; M: male; Pat. No.: Patients number.

To our knowledge, this is the first study reporting the use of mAb KS1/4 coated beads to isolate CTC from CRC patients. The sensitivity of the KS1/4 coated bead system was evaluated by HT29 tumor cell dilution experiments and reproducibly allowed the detection of about $10^{2}$ HT29 cells spiked in $5 \mathrm{ml}$ blood. In our reference experiments, mAb KS1/4 retrieved 10 fold more tumor cells than the commonly used mAb BerEP4 precoated beads $\left(10^{3}\right.$ cells in $5 \mathrm{ml}$ blood) after MNC gradient enrichment.

Our study also confirmed the study from Guo et al. which showed better results for MNC population extraction prior to immunomagnetic isolation of tumor cells than the immunomagnetic isolation of circulating tumor cells from whole blood [16]. Guo et al. combined immunomagnetic isolation followed by real-time RT-PCR to

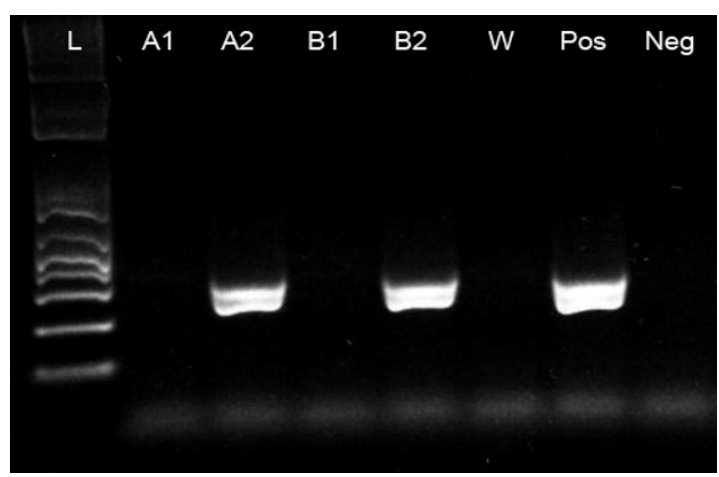

Figure 1 Cytokeratin 20 RT-PCR amplification products after immunomagnetic enrichment with both Ep-CAM antibodies from blood samples of two CRC patients. W, water negative control; POS positive control (HT29 cells); Neg, negative control (blood of healthy person); L, ladder (molecular weight marker). Lanes A1-A2, patient ID 22 and Lanes B1-2, patient ID 23. A2 and B2 show CK20 products after CTC enrichment with $\mathrm{KS} 1 / 4$ beads whereas BerEP4 beads failed to detect CTC in the same patients (A1 and B1). detect CTC in patients with colorectal cancer. This study showed that combining negative (CD45 depletion) and positive (CTC enrichment with BerEP4 beads) immunomagnetic selection successively yields a high amount of CTC (1 CTC/1 ml blood). As they used CEA as marker gene in their analyses, the authors did not assess the cytokeratin expression of the CTC, which is in our opinion the most widely used marker for CTC [16]. Moreover, negative enrichment with CD45 depletion of leucocytes may lead to a theoretical "loss" of CTC as they could stick together with the leucocytes-beads complexes. Denis et al. demonstrated CTC in whole blood samples in 4 of 5 patients with metastatic CRC using mAb BerEP coated magnetic beads and subsequent analysis with RT-PCR assays for CK8, CK19 and CK20 gene expression [15]. However, the previously described epithelial and tumor markers can also be expressed in normal peripheral blood leukocytes normally present in whole blood which may lead to false positive results [16-21]. Using spiking experiments with healthy donor blood Vlems et al. demonstrated that differences in sample handling and assay sensitivity influence CK20 detection in blood [22]. In the present study, isolation of CTC from CRC patients was only performed in the MNC population after Ficoll-gradient enrichment. In addition, Ficoll-gradients purge the MNC fraction from granulocytes, which constitutively express CK20 mRNA [19]. This is in accordance with our results as our nested RT-PCR retrieved consistently negative CK20 results in blood samples from healthy donors. Automated systems for immunomagnetic CTC isolation and subsequent immunocytochemical detection are nowadays available and usually rely on the principle of EpCAM based enrichment methods. Using the Cell Search system (Veridex) Cohen et al. demonstrated the prognostic value of CTC enumeration in the peripheral blood of metastatic CRC patients [23]. Future studies are 
Table 2: Characteristics of the CK20 positive patients and comparison of the two different antibodies used for immunomagnetic enrichment

\begin{tabular}{|c|c|c|c|c|c|}
\hline Pat. No. & Diagnosis & TNM & UICC-Stage & BerEP4-Beads & KS 1/4-Beads \\
\hline 2 & Rectal Cancer & T3 N2 M0 & III & positive & negative \\
\hline 5 & Left Colon Cancer & T2 NO MO & I & negative & positive \\
\hline 9 & $\begin{array}{l}\text { Metachronous liver metastasis from } \\
\text { Rectal Cancer }\end{array}$ & Tx Nx M1 & IV & positive & negative \\
\hline 17 & Right Colon Cancer & T3 N1 Mo & III & positive & negative \\
\hline 22 & $\begin{array}{l}\text { Synchronous liver metastasis from Colon } \\
\text { Cancer }\end{array}$ & T3 N2 M1 & IV & negative & positive \\
\hline 23 & $\begin{array}{l}\text { Metachronous liver metastasis from } \\
\text { Rectal Cancer }\end{array}$ & Tx Nx M1 & IV & negative & positive \\
\hline 25 & Right Colon Cancer & T4 N2 M0 & III & positive & negative \\
\hline 28 & $\begin{array}{l}\text { Synchronous liver and bone metastasis } \\
\text { from Colon Cancer }\end{array}$ & Tx Nx M1 & IV & positive & negative \\
\hline 31 & Rectal cancer & T1 No Mo & 1 & negative & positive \\
\hline 32 & $\begin{array}{l}\text { Metachronous liver metastasis from } \\
\text { Rectal Cancer }\end{array}$ & Tx Nx M1 & IV & positive & negative \\
\hline 37 & $\begin{array}{l}\text { Metachronous liver metastasis from } \\
\text { Rectal Cancer }\end{array}$ & Tx Nx M1 & IV & negative & positive \\
\hline
\end{tabular}

needed to examine and compare the detection rates and prognostic differences between PCR based and immunocytochemical tumor cell detection methods after immunomagnetic enrichment of CTC.

BerEP4 and KS1/4 are high affinity and specific mAb frequently used to detect EpCAM positive cells. Interestingly, we noted that CK20 RT-PCR products were commonly not found in both samples when analyzing blood of the same patient after enrichment with either mAb BerEP4 or mAb KS/4. Other authors have already described heterogeneity in reactivity of EpCAM specific antibodies. Balzar et al. suggested that different conformational states of the cell surface EpCAM protein might hide some epitopes leading to subpopulations of EpCAM and thus heterogeneous affinity [10].

Successful CTC enrichment depends on the level of EpCAM expression in the target cell [24]. Furthermore, downregulation of cytokeratins in tumor derived cell lines and cytokeratin negative CTC have also been reported in patients with breast cancer $[25,26]$. These findings might hinder the adequate detection of CTC. Promising results for the detection of CK20 positive CTC in colorectal cancer patients were shown by Wong et al [27] by blocking the Fc region of the anti-BerEP4 antibody with a goat anti-mouse antibody during immunomagnetic enrichment. Using this refined immunomagnetic enrichment method Wong et al. could demonstrate a specific detection of colorectal CTC in vitro and they confirmed the clinical significance of their results in large series of colorectal cancer patients [27].

The dissimilar capture of CTC by BerEP4 and KS1/4 mAbs in our analysis might be explained by various expression of the EpCAM molecule among the examined patients. Nevertheless, our KS1/4 system was able to retrieve 10 fold more CTC compared to the BerEP4 system. The use of different EpCAM clones might enhance

Table 3: Comparison of tumor cell detection with UICC stage of CRC patients after enrichment with mAb BerEP4 and KS14 coated beads.

\begin{tabular}{cccc}
\hline UICC-Stage & NO. OF PATIENTS & POSITIVE CK20 SAMPLES & BerEP4 \\
& & & \\
KS1/4 & 0 & 0 & 3 \\
II & 7 & 3 & 3 \\
III & 7 & 3 & 3 \\
\hline
\end{tabular}


the detection rate of CTC. Additional investigations to assess the variations of EpCAM molecule expression among different patients will be of critical importance to identify a panel of suitable mAbs which could be used for efficient and reliable CTC isolation.

Our results also demonstrate that Ficoll-gradient isolation is a decisive step prior to the immunomagnetic enrichment of CTC from peripheral blood.

\section{Conclusions}

Our study for the first time shows that isolation and detection of CTC with immunomagnetic enrichment methods is critically dependent on the used EpCAM clone. Further analysis regarding the clinical importance of heterogenous expression of the EpCAM molecule in CTC of CRC patients is urgently needed.

\section{Methods}

\section{Blood samples from healthy donors and patients}

For blood spiking experiments and for testing the specificity of the various extraction and enrichment protocols peripheral blood samples were drawn from the antecubital vein of 5 healthy donors and collected in EDTAcoated tubes (S-Monovette', Sarstedt, Germany). To avoid epithelial cell contamination from skin puncture, the first $5 \mathrm{ml}$ of peripheral blood were discarded. After collection, blood samples were immediately processed for further experiments.

Five $\mathrm{ml}$ blood samples were obtained after induction of general anesthesia (and before start of the operation) through a central venous line from 38 CRC patients (UICC stage I-IV) undergoing surgical therapy at the Department of Surgery, University of Heidelberg, Germany. Patients with histopathologically confirmed CRC were staged according to the classification of the UICC (6 ${ }^{\text {th }}$ edition) [28]. The study protocol was approved by the ethics committee of the University of Heidelberg. Informed consent for blood sampling was obtained from each patient.

\section{Cell spiking experiments}

For cell spiking experiments and the examination of different cell extraction methods, EpCAM and CK20 positive cells from the human colon cancer cell line HT29 were serially diluted in $5 \mathrm{ml}$ blood samples taken from five different healthy donors. Dilutions performed were: $10^{6}, 10^{5}, 10^{4}, 10^{3}, 10^{2}, 10$ and 0 HT2 29 cells per $5 \mathrm{ml}$ whole blood.

\section{HT29 cells}

The human colon cancer cell line HT29 expressing EpCAM and Cytokeratin 20 (CK20) was purchased from American Type Cell Culture (Austria Branch). Cells were cultured in RPMI-1640 Medium with L-glutamine and
HEPES (PAA Laboratories GmbH, Austria) supplemented with $100 \mathrm{U} / \mathrm{ml}$ penicillin, $100 \mu \mathrm{g} / \mathrm{ml}$ streptomycin (PAA Laboratories $\mathrm{GmbH}$, Austria), and $10 \%$ fetal bovine serum (Biochrom AG, Germany) in plastic flasks at $37^{\circ} \mathrm{C}$ in a $5 \% \mathrm{CO}_{2}$ atmosphere. Collection of cells was performed with help of Trypsin-EDTA (PAA Laboratories $\mathrm{GmbH}$, Austria) and centrifugation at room temperature for 3 minutes at $300 \mathrm{~g}$. Cells were then counted with a hemacytometer and viability was confirmed by Trypan blue stain.

\section{Mononuclear cell collection}

The mononuclear cell (MNC) population was extracted according to the following protocol: $5 \mathrm{ml}$ peripheral blood samples were carefully layered over a $15 \mathrm{ml}$ Ficoll gradient (FicoLite- $\mathrm{H}^{\circ}$, Linaris, Germany density 1.077) and covered with $10 \mathrm{ml}$ phosphate buffered saline solution (PBS; PAA Laboratories GmbH, Austria). The samples were spun in a centrifuge at $4{ }^{\circ} \mathrm{C}$ for 30 minutes at 300 $\mathrm{g}$ without brake. Concentrated MNCs were harvested from the interface with the help of a disposable pipette. The isolated cells were washed once in PBS, spun in a centrifuge for 10 minutes at $300 \mathrm{~g}$ and resuspended in 1 $\mathrm{ml}$ PBS. The MNCs were counted with a hemacytometer and then resuspended at $10^{7}$ cells $/ \mathrm{ml}$ in PBS.

Immunomagnetic enrichment and cell extraction protocols The unspiked and spiked (with HT29 cells) blood samples ( $5 \mathrm{ml}$ blood for each experiment) of healthy volunteers were processed using two different cell extraction protocols followed by immunomagnetic enrichment using the device of Dynal MPC-L (Dynal, Norway):

1. Whole blood samples underwent directly an immunomagnetic enrichment ( $10^{7}$ beads per $\mathrm{ml}$ blood) using either Dynabeads Epithelial Enrich (Dynal, Oslo, Norway) coated with mAb BerEP4 or alternatively, Pan Mouse IgG beads (Dynal, Norway) coated ( $1 \mu \mathrm{g}$ antibody $/ 10^{7}$ beads) with the mAb KS1/4 (BD PharMingen, Heidelberg, Germany). The samples were then placed in a roller at $4^{\circ} \mathrm{C}$ for rosetting to occur and after 30 minutes the tubes were placed in a magnetic device for 3 minutes; the blood supernatant was carefully removed and, while the tubes were still on the magnet, rosettes were washed three times with cold PBS.

2. The isolated MNC fraction of the blood sample was counted and resuspended with $10^{7}$ beads, mAb BerEP4 Dynabeads Epithelial Enrich or alternatively, with Pan Mouse IgG beads coated with the MAb KS1/ 4 , per $10^{7} \mathrm{MNCs}$ in $1 \mathrm{ml} \mathrm{PBS}$. Further immunomagnetic processing was done in the same way as described above.

Finally, the rosetted cells were pelleted by centrifugation at $300 \mathrm{~g}$ for 10 minutes and resuspended in $100 \mu \mathrm{l}$ 
PBS. Immediately, the samples were processed for RNA isolation.

In all blood samples from CRC patients isolation of the MNC fraction (prior to immunomagnetic enrichment using the two different EpCAM antibodies) was performed prior to further immunomagnetic enrichment. Immunomagnetic enrichment using the two different EpCAM antibodies was performed as described above.

\section{RNA extraction and nested RT-PCR}

CK20 transcripts were detected after immunomagnetic enrichment of tumor cells either derived from blood samples spiked with HT29 cells or from blood samples drawn from CRC patients.

For the detection of tumor cells a CK 20 nested RTPCR was performed as previously shown $[12,13]$. In brief, total RNA was extracted from the cells immobilized by the magnetic beads added to whole blood or MNC fractions. RNeasy Mini Kit (Qiagen, Hilden, Germany) was used to isolate total RNA according to the manufacturer's instructions. Each sample was eluted in $30 \mu \mathrm{l}$ RNase-free water. For reverse transcription of the RNA the primer CK20 558.rev and the SuperScript II Kit (Invitrogen, Karlsruhe, Germany) was used following manufacturer's instructions. $2 \mu \mathrm{l}$ aliquots of cDNA were used for the CK20 nested-PCR reaction using the Master Mix Kit from Promega (Wisconsin, USA) according to manufacturer's protocol.

For the first PCR cDNA was subjected to amplification of CK20 with primers 1.for (ATGGATTTCAGTCGCAGA) and 558.rev (ATGTAGGGTTAGGTCATCAA AG) in 35 amplification rounds performed at $93^{\circ} \mathrm{C}$ for 51 seconds, $60^{\circ} \mathrm{C}$ for 63 seconds, and $72^{\circ} \mathrm{C}$ for 42 seconds, with a final extension step at $72^{\circ} \mathrm{C}$ for 10 minutes. The nested PCR was performed with $8 \mu$ PCR product of the first PCR with primer 139.for (TCCAACTCCAGACACACGGTGAACTATG) and 429.rev (CAGGACACA CCGAGCATTTT GCAG) under amplification conditions as following: $93^{\circ} \mathrm{C}$ for 51 seconds and $72^{\circ} \mathrm{C}$ for 81 seconds in 35 amplification rounds. PCR products were analyzed by electrophoresis on $2 \%$ agarose gels. RNA quality and performance of reverse transcription of the analyzed samples was confirmed by RT-PCR amplification of GAPDH transcripts.

\section{Authors' contributions}

$D A, L G$, and $A C$ performed the experiments and contributed to clinical data collection and manuscript preparation. NR, MWB, and JW contributed to the conduction of the study and were involved in critical review and revision of the manuscript. MK designed the study and was responsible for manuscript preparation and revision. All authors read and approved the final manuscript

\section{Acknowledgements}

All submitting authors declare that there were no external sources of funding for this study.
Author Details

Department of Surgery, University of Heidelberg, Heidelberg, Germany

Received: 5 October 2009 Accepted: 28 April 2010

Published: 28 April 2010

References

1. Alix-Panabieres $C$, Riethdorf S, Pantel K: Circulating tumor cells and bone marrow micrometastasis. Clin Cancer Res 2008, 14:5013-21.

2. Weitz J, Koch M, Debus J, Hohler T, Galle PR, Buchler MW: Colorectal cancer. Lancet 2005, 365:153-65.

3. Rahbari NN, Aigner M, Thorlund K, Mollberg N, Motschall E, Jensen K Diener MK, Büchler MW, Koch M, Weitz J: Meta-Analysis Shows that Detection of Circulating Tumor Cells Indicates Poor Prognosis in Patients with Colorectal Cancer. Gastroenterology 2010, 138(5):1714-26.

4. Koch M, Beckhove P, Op den Winkel J, Autenrieth D, Wagner P, Nummer D, Specht S, Antolovic D, Galindo L, Schmitz-Winnenthal FH, Schirrmacher $\checkmark$, Buchler MW, et al:: Tumor infiltrating T lymphocytes in colorectal cancer: Tumor-selective activation and cytotoxic activity in situ. Ann Surg 2006, 244:986-92. discussion 92-3

5. Koch M, Kienle P, Kastrati D, Antolovic D, Schmidt J, Herfarth C, von Knebel Doeberitz M, Weitz J: Prognostic impact of hematogenous tumor cell dissemination in patients with stage II colorectal cancer. Int J Cancer 2006, 118:3072-7.

6. Weitz J, Kienle P, Magener A, Willeke F, Lehnert T, Herfarth C, von Knebel Doeberitz M: [Detection of isolated disseminated tumor cells of colorectal carcinomas in lymph nodes]. Langenbecks Arch Chir Suppl Kongressbd 1998, 115:319-22.

7. Weitz J, Kienle P, Lacroix J, Willeke F, Benner A, Lehnert T, Herfarth C, von Knebel Doeberitz M: Dissemination of tumor cells in patients undergoing surgery for colorectal cancer. Clin Cancer Res 1998, 4:343-8.

8. Kienle $P$, Koch M: Minimal residual disease in gastrointestinal cancer. Semin Surg Oncol 2001, 20:282-93.

9. Balzar M, Winter MJ, de Boer CJ, Litvinov SV: The biology of the 17-1A antigen (Ep-CAM. J Mol Med 1999, 77:699-712

10. Balzar M, Briaire-de Bruijn IH, Rees-Bakker HA, Prins FA, Helfrich W, de Leij L, Riethmuller G, Alberti S, Warnaar SO, Fleuren GJ, Litvinov SV: Epidermal growth factor-like repeats mediate lateral and reciprocal interactions of Ep-CAM molecules in homophilic adhesions. Mol Cell Biol 2001 21:2570-80

11. Latza U, Niedobitek G, Schwarting R, Nekarda H, Stein H: Ber-EP4: new monoclonal antibody which distinguishes epithelia from mesothelial. J Clin Pathol 1990, 43:213-9.

12. Perez MS, Walker LE: Isolation and characterization of a CDNA encoding the KS1/4 epithelial carcinoma marker. J Immunol 1989, 142:3662-7.

13. Chambers AF, Groom AC, MacDonald IC: Dissemination and growth of cancer cells in metastatic sites. Nat Rev Cancer 2002, 2:563-72.

14. Fidler IJ: The pathogenesis of cancer metastasis: the 'seed and soil' hypothesis revisited. Nat Rev Cancer 2003, 3:453-8.

15. Denis MG, Lipart C, Leborgne J, LeHur PA, Galmiche JP, Denis M, Ruud E, Truchaud A, Lustenberger P: Detection of disseminated tumor cells in peripheral blood of colorectal cancer patients. Int J Cancer 1997 74:540-4.

16. Guo J, Xiao B, Zhang X, Jin Z, Chen J, Qin L, Mao X, Shen G, Chen H, Liu Z Combined use of positive and negative immunomagnetic isolation followed by real-time RT-PCR for detection of the circulating tumor cells in patients with colorectal cancers. J Mol Med 2004, 82:768-74.

17. de Cremoux P, Extra JM, Denis MG, Pierga JY, Bourstyn E, Nos C, Clough KB, Boudou E, Martin EC, Muller A, Pouillart P, Magdelenat H: Detection of MUC1-expressing mammary carcinoma cells in the peripheral blood of breast cancer patients by real-time polymerase chain reaction. Clin Cancer Res 2000, 6:3117-22.

18. Jung R, Kruger W, Hosch S, Holweg M, Kroger N, Gutensohn K, Wagener C, Neumaier M, Zander AR: Specificity of reverse transcriptase polymerase chain reaction assays designed for the detection of circulating cancer cells is influenced by cytokines in vivo and in vitro. Br J Cancer 1998, 78:1194-8.

19. Jung R, Petersen K, Kruger W, Wolf M, Wagener C, Zander A, Neumaier M: Detection of micrometastasis by cytokeratin 20 RT-PCR is limited due to stable background transcription in granulocytes. Br J Cancer 1999, 81:870-3. 
20. Lopez-Guerrero JA, Bolufer-Gilabert P, Sanz-Alonso M, Barragan-Gonzalez E, Palau-Perez J, De la Rubia-Comos J, Sempere-Talens A, Bonanad-Boix S: Minimal illegitimate levels of cytokeratin K19 expression in mononucleated blood cells detected by a reverse transcription PCR method (RT-PCR). Clin Chim Acta 1997, 263:105-16.

21. Traweek ST, Liu J, Battifora H: Keratin gene expression in non-epithelial tissues. Detection with polymerase chain reaction. Am J Pathol 1993, 142:1111-8.

22. Vlems F, Soong R, Diepstra H, Punt C, Wobbes T, Tabiti K, van Muijen G: Effect of blood sample handling and reverse transcriptase-polymerase chain reaction assay sensitivity on detection of CK20 expression in healthy donor blood. Diagn Mol Pathol 2002, 11:90-7.

23. Cohen SJ, Punt CJ, lannotti N, Saidman BH, Sabbath KD, Gabrail NY, Picus J Morse M, Mitchell E, Miller MC, Doyle GV, Tissing H, Terstappen LW, Meropol NJ: Relationship of circulating tumor cells to tumor response, progression-free survival, and overall survival in patients with metastatic colorectal cancer. J Clin Oncol 2008, 26(19):3213-21.

24. Paterlini-Brechot $P$, Benali NL: Circulating tumor cells (CTC) detection: clinical impact and future directions. Cancer Lett 2007, 253:180-204.

25. Fehm T, Sagalowsky A, Clifford E, Beitsch P, Saboorian H, Euhus D, Meng S, Morrison L, Tucker T, Lane N, Ghadimi BM, Heselmeyer-Haddad K, Ried T, Rao C, Uhr J: Cytogenetic evidence that circulating epithelial cells in patients with carcinoma are malignant. Clin Cancer Res 2002, 8:2073-2084.

26. Willipinski-Stapelfeldt B, Riethdorf S, Assmann V, Woelfle U, Rau T, Sauter G, Heukeshoven J, Pantel K: Changes in cytoskeletal protein composition indicative of an epithelial-mesenchymal transition in human micrometastatic and primary breast carcinoma cells. Clin Cancer Res 2005, 11:8006-8014.

27. Wong SC, Chan CM, Ma BB, Hui EP, Ng SS, Lai PB, Cheung MT, Lo ES, Chan AK, Lam MY, Au TC, Chan AT: Clinical significance of cytokeratin 20positive circulating tumor cells detected by a refined immunomagnetic enrichment assay in colorectal cancer patients. Clin Cancer Res 2009, 15(3):1005-12.

28. Wittekind Ch, Meyer HJ, Bootz F: TNM Klassifikation maligner Tumoren. In 6. Auflage Springer Verlag; 2003.

doi: $10.1186 / 1472-6750-10-35$

Cite this article as: Antolovic et al., Heterogeneous detection of circulating tumor cells in patients with colorectal cancer by immunomagnetic enrichment using different EpCAM-specific antibodies BMC Biotechnology 2010, $10: 35$

Submit your next manuscript to BioMed Centra and take full advantage of:

- Convenient online submission

- Thorough peer review

- No space constraints or color figure charges

- Immediate publication on acceptance

- Inclusion in PubMed, CAS, Scopus and Google Scholar

- Research which is freely available for redistribution

Submit your manuscript at www.biomedcentral.com/submit
C) Biomed Central 